InOedia $\quad \begin{aligned} & \text { InMedia } \\ & \text { The French Journal of Media Studies }\end{aligned}$

$2 \mid 2012$

Performing/Representing Male Bonds

\title{
The Translation and Reception of Multilingual
} Films

15-16 June 2012, Université Paul-Valéry Montpellier 3

\section{Samuel Bréan et Jean-François Cornu}

\section{OpenEdition}

\section{Journals}

Édition électronique

URL : https://journals.openedition.org/inmedia/486

DOI : 10.4000/inmedia.486

ISSN : 2259-4728

Éditeur

Center for Research on the English-Speaking World (CREW)

Référence électronique

Samuel Bréan et Jean-François Cornu, «The Translation and Reception of Multilingual Films », InMedia [En ligne], 2 | 2012, mis en ligne le 06 décembre 2012, consulté le 21 septembre 2021. URL http://journals.openedition.org/inmedia/486 ; DOI : https://doi.org/10.4000/inmedia.486

Ce document a été généré automatiquement le 21 septembre 2021.

(c) InMedia 


\section{The Translation and Reception of Multilingual Films}

15-16 June 2012, Université Paul-Valéry Montpellier 3

Samuel Bréan et Jean-François Cornu

\section{NOTE DE L'ÉDITEUR}

Conference organised by Jean-Marc Lavaur and Adriana şerban

1 Audiovisual translation studies is an active, albeit fairly recent, field. The translation of films is almost as old as cinema itself, since intertitles appeared in the early 1900s, but the advent of sound film turned out to be a mixed blessing for the film industry: solutions had to be found so that movies could keep travelling 'abroad', i.e. out of their linguistic spheres. Subtitling, dubbing and voice-over are the three main methods used nowadays (though the latter is generally not associated with fiction films ). Little attention was given to audiovisual translation before the 1990s, but since then, publications and conferences have blossomed. Given its hybrid nature, the topic attracts attention from scholars in translation studies, film studies, and the sociology of cinema.

2 Research is especially active in Europe, with two regular international conferences (Languages and the Media, Media for All) and a research group, ESIST (European Association for Studies in Screen Translation, set up in 1995). So far, however, conferences in France on the topic have been few and far between. The June 2012 conference in Montpellier followed a previous one entitled "Audiovisual Translation: Multidisciplinary Approaches", held in 2008. ${ }^{1}$ This time the topic was more focused. This seems a reasonable approach, given the vast variety of subjects generally tackled in conferences on audiovisual translation, sometimes with mixed results. In this case, the topic of multilingual films allowed for a wider and more diverse range of papers than we expected. 
3 Contributions dealing with multilingual films focused mainly on themes (multiculturalism, immigration, war films), case studies of specific scenes or films (Close Encounters of the Third Kind, Inglorious Basterds) and the presentation of work in progress. Some researchers took into consideration the constraints imposed on the translator, others measured the 'degree' of multilingualism in polyglot films.

4 Multilingualism was examined from three major perspectives: as a narrative and aesthetic element of a film, including cultural identity issues; from a reception point of view, especially with monolingual audiences; and as a specific problem for translators who devise various strategies to solve it.

5 Each day began with a keynote speech. Reine Meylaerts, a professor of comparative literature at the Katholieke Universiteit, in Leuven, Belgium, opened the conference with a communication entitled "Multilingualism and the limits of translation". After reviewing the background to the topic, she focused on specific aspects of multilingualism in film and their impact on audiovisual translation. Meylaerts mentioned that most studies on the subject are about literary works, emphasizing the scarcity of such studies related to cinema. The 19th-century romantic ideal in terms of language (one nation = one language) has been dropped, she said, in favour of a more prominent space given to multilingualism in literature since the postcolonial period. As regards cinema, Meylaerts asked whether film was less dependent on language(s) and examined the situation from a translation perspective. In the case of multilingual films, film-making and translation overlap, which places the translation process not so much in-between as within the text or film. Yet, Meylaerts claims that the multilingual film translator's task is neither mere craftsmanship nor brilliant creativity, but lies somewhere in-between.

6 In the second keynote address, freelance translator and researcher Jean-François Cornu specifically focused on what becomes of multilingual films when put to the test of dubbing and subtitling. He gave a broad definition of what a multilingual film is, highlighting the fact that a film is by definition a multilingual object made up of image and sound-languages in their own right. Narrowing the definition, he dealt with multilingual films as, of course, films involving more than one 'natural' language in their dialogue and narration. Cornu outlined a rough typology of multilingual films based on the presence of various languages or forms of languages within one film, including regional or other accents and the more controversial issue of puns and wordplay. Such a variety of 'multilingual' films calls for equally diverse translation strategies ranging from total respect of multilingualism to imposed monolingualism, such as in the French- and Italian-dubbed versions of Liliana Cavani's La Pelle (1981), whose original version involved English, Italian, German and French. This gave Cornu the opportunity to reflect on an increasingly sensitive and researched issue in film studies, the concept of the version originale or 'original version'. He concluded by emphasizing the fact that audiovisual translation was by no means an end in itself, but one of the tools of film language in its own right.

7 Lisbon-based scholar Francine Arroyo's paper similarly contended that wordplay is a kind of "foreign language within a language". Arroyo focused on a character in a littleknown film by a popular director, Jean-Pierre Jeunet's Micmacs à tire-larigot (2009), whose lines are almost entirely comprised of idiomatic expressions. Her thorough examination included a phraseological breakdown of the expressions and a close look at the Portuguese subtitler's translation strategies. Arroyo's paper was also valuable 
because of the account she gave of working conditions in Portugal: the translator only had 48 hours to subtitle this film, which makes it nearly impossible to achieve a satisfying translation.

8 A number of contributions came under the general heading of multilingualism as a narrative device. The film-maker's perspective was examined from various angles. With "The Tower of Babel in cinema: the role of language and translation strategies in original polyglot films", Elena Sanz Ortega, a PhD student in Edinburgh, probed the reasons behind a film-maker's choice of a multilingual narrative and how the use of several languages contribute to the storyline. She emphasized the reasons for and challenges of shooting a polyglot film and the subsequent strategies involved in translating such films. Another PhD student from Bologna, Giuseppe de Bonis, introduced the audience to a specific case study with "Alfred Hitchcock presents: multilingualism as a vehicle for... suspense". To highlight the crucial role of multilingualism in Hitchcock's films, de Bonis devised an impressive typology of the 14 films by the master of suspense which include more than one language. He also examined the translation solutions chosen for the Italian-dubbed versions of those films.

9 These contributions showed that studying the issue from the film-maker's perspective is indeed interesting from an artistic point of view. Yet one may feel that the implications for translation strategies may not differ that much from those involved in the translation of monolingual films, in the sense that knowing the director's initial reasons may not be fundamental to making a good job of translating his or her film. As for Hitchcock's films, apart from Torn Curtain and Topaz which both include a number of European languages for narrative purposes, it can hardly be said that multilingualism is a crucial factor of suspense in the great master's filmography.

10 The narrative issue was also looked at from the viewer's perspective by University of Bologna professor Delia Chiaro in her talk called "Mixed languages, mixed sensations: the emotional rollercoaster of multilingual films." Her main point was that multilingual films are not a specific genre, but cut across film genres. ${ }^{2}$ They involve polyglot performance on the part of the actors, as well as translation within the film, not just towards an audience. She added that the use of different languages also has to do with triggering specific emotions in the audience, especially in American post-war comedies (such as identifying German as the language of oppression, or 'comically' mispronouncing foreign names).

11 In an impressive paper, Ilaria Parini (University of Milan) looked at the puzzling differences between the Italian dubbing of Cédric Klapisch's L'Auberge espagnole (2001) and that of its sequel, Les Poupées russes (2005). Both films feature characters from various countries who speak in their own language or in a language understood by all (generally English). While the dubbing of L'Auberge keeps a certain number of foreign elements (subtitled dialogue, accented deliveries), that of Les Poupées all but erases them. This is due, Parini explained, to the role of the distributors: they shied away from carrying over the same translation strategy from one film to the next - rather incomprehensibly, since L'Auberge was a success in the first place. Parini concluded by regretting the lack of consistency implied by the distributors' decision and their lack of respect for spectators likely to be disappointed by the sequel of a film they liked.

12 Other case studies focused on the role of interpreters in multilingual films: Lucía Ruiz Rosendo addressed the issue through a selection of films in which different kinds of 
interpreters appear (professionals, non-professionals, interpreters in conflict zones). Others dealt with the problem of dubbing into French a French character speaking French in an American film (Simon Labate on Truffaut's performance in Steven Spielberg's Close Encounters of the Third Kind). The theme of immigration was brought up in two papers: Irene de Hinges Andino's “Ideological implications in the translation of multilingual films" (on migration and diasporic cinema) and Marie Biscio's "French polyglot cinema in translation". Both scholars have defined a corpus of films for their research and aim to study the importance of language in the depiction of immigrant characters, and especially its impact in terms of identity and integration. Both studies are still at a fairly early stage but promise well for the future.

of course, Quentin Tarantino's Inglorious Basterds was the multilingual film of recent years which was most quoted and studied in depth. Two contributors presented specific studies on the film: Cristina Huertas Abril reviewed the difficulties of dubbing and subtitling it and the strategies used to convey its crucial polyglot narrative, while Anne-Lise Weidmann undertook a comparative study of four dubbed versions of the film, showing that the coherence of the original film was somewhat lost in the process. ${ }^{3}$ The film may not be to everybody's taste. However, Inglorious Basterds is indeed fascinating for its use of multilingualism as a major narrative device. The opening sequence, where a Nazi officer has a tense discussion with a French farmer, involves French and English in the original version, with a switch from French into English at a defining moment. This was obviously one of the major problems for the makers of the French dubbed version who had to come up with other ideas to maintain the dramatic tension. Other scenes offer similar problems, with other languages at stake. The presence of German makes it difficult for the German dubbers to remain somewhat faithful to the director's vision. Yet, here again, comparative studies reach their limits. Dubbed versions are easy prey for criticism, while subtitled versions are considered loyal to the original film. Indeed, each dubbed version of Inglorious Basterds has its own defects, but each was made with care. On the whole, the general atmosphere and plot were successfully maintained. Academic studies could gain a lot from considering a given film's dubbed version for its own qualities and drawbacks, as long as it does not overtly betray the original. This report is obviously a partial one, since it was impossible to attend all presentations. Other aspects included reception studies, audiodescription, accessibility, 'surtitling' (subtitling for the stage) - the three latter falling into a wider and looser category: 'adaptation' rather than translation.

To conclude, the third Montpellier conference on audiovisual translation was a major event in advancing academic and independent research in the field. It included a growing number of professional translators, as well as researchers who seem to be increasingly aware of the working conditions and constraints audiovisual translators are confronted with. Academics, especially from the younger generation, now acknowledge this. The conference also contributed to filling the gap between audiovisual translation studies and film studies. The good news is that some researchers are gradually leaving behind old literary translation concepts ill-applied to audiovisual translation. In the process, they are acknowledging the fact that to study a piece of audiovisual translation, one should be aware that this form of translation involves a good understanding and awareness of how a film or audiovisual production works. However, university researchers often feel the need to provide frameworks for 
translation strategies and translators. This may be considered as a recurrent flaw in some of their studies. Whether multilingual or monolingual, each film is different in its own right and provides a specific translation challenge. Attempts to 'over-theorize' or to impose frameworks on day-to-day translation practices do not always lead to fruitful results.

The conference ended with three university researchers presenting a stimulating initiative, the creation of a network of studies on multilingual films. The idea is to set up a worldwide database of multilingual films and to foster exchanges between researchers interested in the subject. Conference participants will all be kept informed of the development of this network.

The publication of the proceedings is currently scheduled for the end of 2014, in a special issue of Linguistica Antverpiensia, New Series - Themes in Translation Studies (LANS TTS, http://www.lans-tts.be/).

\section{NOTES}

1. See Adriana şerban and Jean-Marc Lavaur eds, Traduction et médias audiovisuels (Villeneuve d'Ascq: Presses Universitaires du Septentrion, 2011) and Adriana şerban, Anna Matamala and Jean-Marc Lavaur eds, Audiovisual Translation in Close-Up (Bern: Peter Lang, 2011).

2. The case for multilingual films as a genre was notably made by Chris Wahl. See Chris Wahl, "Discovering a genre: the polyglot film," Cinemascope 1 (2005), accessed July 31, 2012, http:// www.cinemascope.it.

3. Weidmann's paper will be included in the "Retour sur Inglorious Basterds" dossier, on the Association des Traducteurs/Adaptateurs de l'Audiovisuel (ATAA) blog, accessed July 31, 2012, http://www.ataa.fr/blog/category/retour-sur-inglourious-basterds/.

\section{AUTEURS}

\section{SAMUEL BRÉAN}

Translator and independent researcher, member of ATAA (Association des Traducteurs Adaptateurs de l'Audiovisuel)

\section{JEAN-FRANÇOIS CORNU}

Translator and independent researcher, member of ATAA (Association des Traducteurs Adaptateurs de l'Audiovisuel) 